\title{
A Validated Stability Indicating Reversed Phase High Performance Liquid Chromatographic Method of Leflunomide and Characterization of Its Degradation Products through Retro-Synthesis
}

\author{
Tapas Kumar Laha*, Subrata Sen \\ Acharya Prafulla Chandra Ray Memorial Cancer Chemotherapeutic Research Unit, College of Pharmaceutical Sciences, Mohuda, Ganjam, Berhampur- \\ 760002, Orissa, India.
}

\begin{tabular}{|c|c|}
\hline ARTICLE INFO & ABSTRACT \\
\hline Article history: & \multirow{10}{*}{$\begin{array}{l}\text { The present paper deals with the development of stability indicating a reversed phase high-performance liquid } \\
\text { chromatographic (RP-HPLC) method for leflunomide, a disease-modifying antirheumatic drug in presence of its } \\
\text { degradation products formed during forced decomposition studies. Forced degradation studies were performed } \\
\text { on the bulk drug by using acid }(0.1 \mathrm{~N} \text { hydrochloric acid), base }(0.1 \mathrm{~N} \text { sodium hydroxide), water (neutral } \\
\text { hydrolysis), } 3 \% \mathrm{v} / \mathrm{v} \text { hydrogen peroxide (oxidation), dry heat }\left(60^{\circ} \mathrm{C}\right) \text { and } \mathrm{UV} \text { light }(254 \mathrm{~nm}) \text {. Degradation was } \\
\text { observed for leflunomide in acidic and basic media only and the formed degradation products were found to be } \\
5 \text {-methylisoxazole- } 4 \text {-carboxylic acid (degradation product- } 1) \text { and } 4 \text {-(trifluoromethyl)-aniline (degradation } \\
\text { product- } 2 \text { ). Successful separation of the drug from the degradation products formed under different stress } \\
\text { conditions was achieved on a Novapak } \mathrm{C} 18 \text { column }(150 \mathrm{~mm} \times 3.9 \mathrm{~mm}, 4 \mu \mathrm{m} \text { particle size) using methanol- } \\
\text { phosphate buffer (pH } 5.3 ; 20 \mathrm{mM})(7: 3 \text {, v/v) as the mobile phase at a flow rate of } 1 \mathrm{~mL} / \mathrm{min} \text {. The detection } \\
\text { wavelength was } 260 \mathrm{~nm} \text {. The developed method was completely validated and proved to be robust. As the } \\
\text { method could effectively separate the drug from its degradation products, it can be employed for analysis of the } \\
\text { samples of stability study. }\end{array}$} \\
\hline Received on: $12 / 03 / 2017$ & \\
\hline Accepted on: 30/04/2017 & \\
\hline Available online: $30 / 05 / 2017$ & \\
\hline & \\
\hline HPLC, Leflunomide, & \\
\hline Stability, Synthesis, & \\
\hline Characterization, FTIR, Mass & \\
\hline Spectrometry, NMR & \\
\hline spectroscopy. & \\
\hline
\end{tabular}

\section{INTRODUCTION}

The chemical name of leflunomide is $\mathrm{N}-4^{\prime}-$ trifluoromethylphenyl)-5-methylisoxazole-4-carboxamide (Kher et al., 2011), which is an isoxazole derivative and inhibitor of de novo pyrimidine synthesis (Katarzyna et al., 1998; Migita et al., 2005), represents a new class of disease modifying anti rheumatic drugs (Yadav et al., 2010). The primary mode of action of leflunomide is specific inhibition of dihydro-orotate dehydrogenase, a key enzyme in the de novo synthesis of pyrimidine, and subsequent inhibition of RNA and DNA

\footnotetext{
* Corresponding Author

Tapas Kumar Laha, Acharya Prafulla Chandra Ray Memorial Cancer Chemotherapeutic Research Unit, College of Pharmaceutical Sciences, Mohuda, Ganjam, Berhampur-760002, Orissa, India.

Email: tapaslaha80 @ rediffmail.com
}

synthesis (Fox, 1998), also a blockade of tumor necrosis factor mediated activation of the transcription factor NF-kB (Manna and Aggarwal, 1999). During our literature survey, very few articles related to the spectrophotometric (Abbas et al., 2006; Shokry et al., 2012), HPLC (Vivien et al., 2004; Miron et al., 2006; Yeniceli et al., 2006; Rao et al., 2008; Kher et al., 2011) and LC-MS (Molinaro et al., 2005) methods of analysis of leflunomide were found. However, most of these reported methods were related to the routine analysis of leflunomide in pharmaceutical dosage forms or metabolite study in human plasma. To our current knowledge, no article related to the stability indicating high performance liquid chromatographic (HPLC) determination of leflunomide and characterization of its degradation products has been reported yet, as revealed by literature survey. Therefore the aim of this study was to develop and validate stability-indicating reversed phase high performance liquid chromatography (RP-HPLC) method 
for determination of leflunomide in presence of its degradation products formed under different stress conditions. The stability assessment of any promising drug candidate plays a vital role in its preformulation study. Many environmental conditions such as heat, light, moisture as well as the inherent chemical susceptibility of a compound to hydrolysis or oxidation play an important role in pharmaceutical stability. So, this study also helps to define storage and handling conditions. The exposition of the drug substance to extreme external conditions helps to reveal and identify the likely degradation products which will open a new scope of research on toxicity study. The findings of toxicity study will help in the scrupulous determination of expiry, adverse effects etc.

\section{MATERIALS AND METHODS}

\section{Materials}

Pure leflunomide (Fig. 1a) was provided by Sun Pharmaceutical Industries Ltd., Sikkim, India and its degradation products namely 5-methylisoxazole-4-carboxylic acid (Fig. 1c) and 4-(trifluoromethyl)-aniline (Fig. 1b) were synthesized by conventional synthetic procedures in our own laboratory. The probable degraded compounds were divined through retrosynthesis. The probable degradation is depicted in Fig. 1. Methanol and water of HPLC grade and were purchased from Merck (India) Ltd., Mumbai, India. All other chemicals and reagents used were of analytical grade and were purchased from Sigma-Aldrich, Mumbai, India.

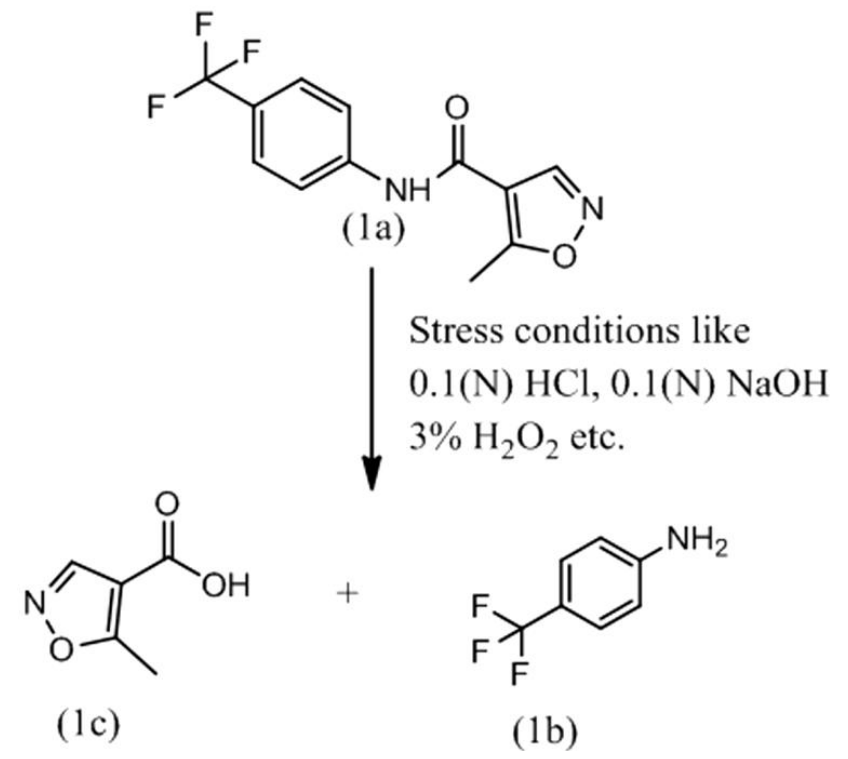

Fig. 1: The probable degradation products of pure leflunomide.

\section{Methods}

Apparatus

Experiments were performed using a Waters (India) 510 HPLC system with Waters 486 tunable absorbance detector. The samples were injected manually using a $20 \mu \mathrm{L}$ sample loop. The
Millennium software was used for quantification and data processing.

\section{Synthesis of 5-methylisoxazole-4-carboxylic acid}

A $50 \mathrm{~mL}$ solution of hydroxylamine hydrochloride (A) $(19 \mathrm{~g}, 0.27 \mathrm{~mol})$ and sodium acetate trihydrate (B) $(37 \mathrm{~g}, 0.27 \mathrm{~mol})$ was added to another $50 \mathrm{~mL}$ ethanol solution containing $(E)$-ethyl 2- (ethoxymethylene)-3-oxobutanoate (C) (50.27 g, $0.27 \mathrm{~mol})$. The mixture was stirred for $2 \mathrm{~h}$ and kept overnight at $0^{\circ} \mathrm{C}$. Then the product 5-methylisoxazole-4-carboxylate was extracted with dichloromethane $(3 \times 30 \mathrm{~mL})$. Thereafter, it was refluxed together with acetic acid $(30 \mathrm{~mL})$, water $(30 \mathrm{~mL})$, and concentrated $\mathrm{HCl}$ $(30 \mathrm{~mL})$ for $10 \mathrm{~h}$ to get the crude 5-Methylisoxazole-4-carboxylic acid. The final compound was recrystallized from ethanol to get the pure 5-Methylisoxazole-4-carboxylic acid (D) (26.07 g).The synthetic pathway is shown in Fig. 2.

White solid, Yield $76 \%, 26.07 \mathrm{~g}, \mathrm{mp} 145-148^{\circ} \mathrm{C}$; IR (KBr disk): 3114 (C-H Str), 3081.46 (O-H Str), 1696.24 (C=O Str), 1602.12 (C-C Ar Ring), 1211 (C-O Str). ${ }^{1} \mathrm{H}$ NMR: 300MHz, DMSO-d 6 : $\delta 13.12$ (1H,br,-COOH), $8.771(1 \mathrm{H}, \mathrm{s}, \mathrm{Ar}-\mathrm{H}), 2.61(1 \mathrm{H}$, s, $\left.-\mathrm{CH}_{3}\right) .{ }^{13} \mathrm{C}$ NMR: $75 \mathrm{MHz}, \mathrm{DMSO}^{-\mathrm{d}_{6}}: 173.76,162.53,150.77$, 109.83, 12.09. MS: $128.08(\mathrm{M}+\mathrm{H})$.<smiles>CCOC=C(C(C)=O)C(=O)OCC</smiles>

(C)
$+\mathrm{NH}_{2} \mathrm{OH} . \mathrm{HCl}+\mathrm{CH}_{3} \mathrm{COONa}$

(A)

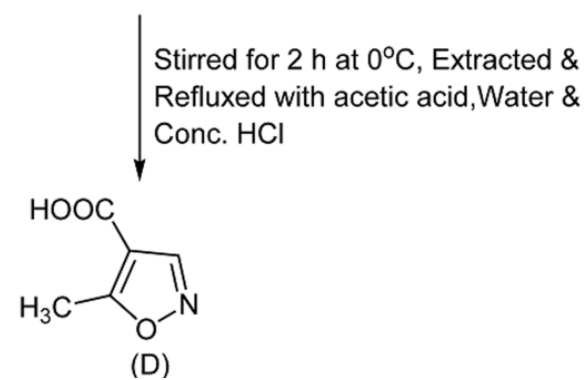

Fig. 2: Synthetic pathway of 5-methylisoxazole-4-carboxylic acid.

\section{Synthesis of 4-(trifluoromethyl)-aniline}

A mixture of $96 \%$ by weight of sulphuric acid (56 g) and $100 \%$ fuming nitric acid ( $56 \mathrm{~g}$ ) was admixed with benzotrichloride (A) $(100 \mathrm{~g})$ at -7 to $0^{\circ} \mathrm{C}$ by drop wise addition over $4 \mathrm{~h}$. The reaction mixture was then initially warmed to $10^{\circ} \mathrm{C}$ for $30 \mathrm{~min}$ then discharged onto the ice and finally extracted with dichloromethane $(3 \times 50 \mathrm{~mL})$. The combined organic phase was washed with water $(100 \mathrm{~mL})$, saturated aqueous sodium bicarbonate solution $(3 \times 50$ $\mathrm{mL})$ and aqueous sodium chloride solution $(50 \mathrm{~mL})$. The organic phase was dried over anhydrous magnesium sulphate and evaporated. A liquid product (B) (120.7 g), a mixture of $80.6 \%$ of 3-nitrobenzotrichloride and $19.4 \%$ of 4-nitrobenzotrichloride was obtained. After calculation about $113 \mathrm{~g}$ of the 3- and 4-nitrobenzotrichloride mixture was then added drop-wise to $85 \mathrm{~mL}$ of anhydrous hydrofluoric acid at an internal temperature between 2 
and $7^{\circ} \mathrm{C}$ in course of $15 \mathrm{~min}$. This was followed by stirring for 17 $\mathrm{h}$ at room temperature and $8 \mathrm{~h}$ at $150^{\circ} \mathrm{C}$ and 25 bar pressure, in a reaction autoclave. The reaction mixture was cooled down to room temperature and distilled to remove excess of hydrofluoric acid. The residue was distilled to obtain $69 \mathrm{~g}$ of a mixture of 3- and 4nitrobenzotrifluoride (C). This mixture was separated by final distillation to obtain $52.16 \mathrm{~g}$ of 3-nitrobenzotrifluoride and $11.05 \mathrm{~g}$ of 4-nitrobenzotrifluoride (D). About $11 \mathrm{~g}$ of the prepared 4nitrobenzotrifluoride and $1 \mathrm{~g}$ of Raney nickel were added to 100 $\mathrm{mL}$ of methanol and subjected to a pressure of 10 bar at ${ }^{\circ} \mathrm{C}$ for 40 $\mathrm{h}$. Thereafter, the reaction mixture was filtered and the filtrate was evaporated to obtain $8 \mathrm{~g}$ of 4-trifluoromethylaniline (E). The compound was purified by using flash chromatography. The synthetic pathway is shown in Fig. 3.

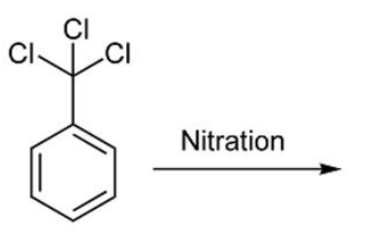

(A)

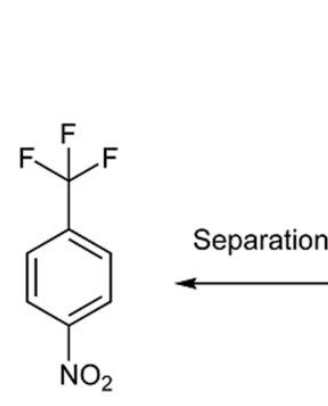

(D)

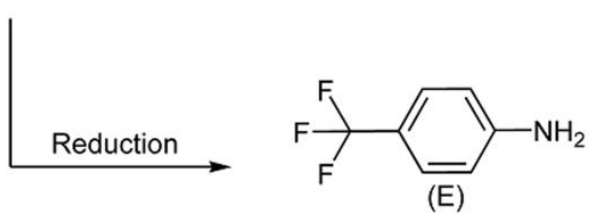

Fig. 3: Synthetic pathway of 4-(trifluoromethl)-aniline.

White solid, Yield $82 \%, 7.60 \mathrm{~g}, \mathrm{mp} 5-8^{\circ} \mathrm{C}$, bp $82-84^{\circ} \mathrm{C}$; IR (KBr disk): 3504.23, 3422.66 (NH Str), 1645.44 (NH Def), 1332.66 (C-N Str), 1249.32, 1178.14, 1137.92, 1079.82 (C-F str) ${ }^{1} \mathrm{H}$ NMR: 300MHz, DMSO-d 6 : $\delta 7.35(2 \mathrm{H}, \mathrm{d}, \mathrm{J}=7.8 \mathrm{~Hz}, \mathrm{Ar}-\mathrm{H})$, $6.64(2 \mathrm{H}, \mathrm{d}, \mathrm{J}=7.8 \mathrm{~Hz}, \mathrm{Ar}-\mathrm{H}), 3.46\left(2 \mathrm{H}, \mathrm{s},-\mathrm{NH}_{2}\right) .{ }^{13} \mathrm{C} \mathrm{NMR}$ : $75 \mathrm{MHz}$, DMSO-d $\mathrm{d}_{6}: 150.69,126.39,125.92,124.22,115.67 . \mathrm{MS}:$ $162.07(\mathrm{M}+\mathrm{H})$.

\section{Chromatographic conditions}

The experiment was performed on a Novapak C18 (150 $\mathrm{mm} \times 3.9 \mathrm{~mm}, 4 \mu \mathrm{m}$ particle size) column using the methanolphosphate buffer (pH 5.3; $20 \mathrm{mM})(7: 3, \mathrm{v} / \mathrm{v})$ as the mobile phase at a flow rate of $1 \mathrm{~mL} / \mathrm{min}$. The mobile phase was filtered through a nylon membrane filter paper (pore size $0.45 \mu \mathrm{m}$ ) and degassed using a sonicator for $10 \mathrm{~min}$. The column temperature was maintained at $25^{\circ} \mathrm{C}$ and eluents were monitored at a wavelength of $260 \mathrm{~nm}$. The volume of each injection was $20 \mu 1$.

\section{Sample preparation}

The standard and sample stock solutions of leflunomide were prepared separately in a solvent mixture of methanolphosphate buffer $(\mathrm{pH} 5.3 ; 20 \mathrm{mM})(7: 3, \mathrm{v} / \mathrm{v})$ at a concentration of $1000 \mu \mathrm{g} / \mathrm{mL}$. Working standard solutions were prepared by diluting the standard stock solution with above solvent to get solutions of concentration in the range of $5-100 \mu \mathrm{g} / \mathrm{mL}$. A stock solution of degradation product-1 and $2(500 \mu \mathrm{g} / \mathrm{mL})$ were also prepared separately in the mobile phase.

\section{Degradation studies}

All the degradation studies were carried out with drug solution of $100 \mu \mathrm{g} / \mathrm{mL}$ concentration. For acidic and alkaline hydrolysis studies, the drug was mixed with $0.1(\mathrm{~N}) \mathrm{HCl}$ and $0.1(\mathrm{~N}) \mathrm{NaOH}$ separately. These mixtures were refluxed on a water bath for $4 \mathrm{~h}$ at $60^{\circ} \mathrm{C}$. The forced degradation in acidic and basic media was performed in the dark in order to exclude the possible degradative effect of light. The resulting solutions were neutralized by base and acid, respectively to avoid any interference of acid or base in the following steps. $20 \mu \mathrm{L}$ of resulting solutions were injected into HPLC system and the chromatograms were recorded. About $20.09 \%$ and $88.26 \%$ degradation of the drug were observed for acidic and basic media, respectively. Among acid hydrolysis products, degradation product-1 was (about $19.19 \%$ ) observed at RT $1.150 \mathrm{~min}$ and degradation product-2 was (about $0.90 \%$ ) observed at RT $1.449 \mathrm{~min}$. In basic hydrolysis, degradation product-1 was (about $85.28 \%$ ) observed at RT $1.150 \mathrm{~min}$ and degradation product-2 was (about 2.98\%) observed at RT 1.449 min. When leflunomide was subjected to oxidative degradation by treating with $3 \%$ hydrogen peroxide solution for $24 \mathrm{~h}$ at ambient temperature, no significant change was observed. The aqueous solution of leflunomide refluxed for $6 \mathrm{~h}$ on a water bath set at $60^{\circ} \mathrm{C}$ for wet heat degradation study, no degradation was found. The drug product was also stored in an incubator at $60^{\circ} \mathrm{C}$ for $72 \mathrm{~h}$ for dry heat degradation study and exposing to direct UV light ( $254 \mathrm{~nm}$ ) for $24 \mathrm{~h}$ for photochemical stability study. The drug was stable in both the cases. In all cases, degradation product-1 and 2 were confirmed by co-injection.

\section{Validation of the Method}

The optimized analytical method was validated appropriately with respect to the following parameters.

\section{Specificity}

Specificity is the ability of the method to measure the analyte response in the presence of its potential degradation products. Degradation conditions employed were UV light (254 $\mathrm{nm}$ for $24 \mathrm{~h}$ ), thermal exposure to $60^{\circ} \mathrm{C}$ for $72 \mathrm{~h}$, acid hydrolysis with $0.1 \mathrm{~N} \mathrm{HCl}$, base hydrolysis with $0.1 \mathrm{~N} \mathrm{NaOH}$, water hydrolysis 
and oxidative degradation using $3 \% \mathrm{H}_{2} \mathrm{O}_{2}$ at ambient temperature for $24 \mathrm{~h}$. Peak purity testing was carried out on the stressed samples of leflunomide by using UV detector.

\section{Precision}

Precision was established for the developed method by spiking the degradation products at target concentration level in the test solution containing the drug product. Six spiked samples were prepared and injected to prove the precision of the method. The $\%$ RSD of all individual degradation products was found to be satisfactory for all the six analytical measurements. This was also repeated on different days to determine inter-day precision. A different scientist established intermediate precision through separation studies on a different chromatographic system. Standard solutions of three different concentrations of leflunomide were prepared and injected six times. The relative standard deviation was determined via the peak area to measure the precision of the LC system.

\section{Limit of detection (LOD) and Limit of quantification (LOQ)}

The LOD and LOQ for leflunomide, degradation product-1 and 2 were estimated at a signal-to-noise ratio of $3: 1$ and 10:1, respectively by injecting a series of dilute solutions of known concentration (ICH 1995). The precision study was also performed at the LOQ level by injecting six individual preparations of leflunomide, degradation product- 1 and 2 by calculating the $\%$ RSD of the AUC.

\section{Accuracy}

The accuracy of the method was evaluated at three concentration levels $(20,50$, and $80 \mu \mathrm{g} / \mathrm{mL})$ of the drug. Accuracy determination of the degradation products was also carried out six times at $40 \%, 80 \%$ and $120 \%$ of the specific concentration level $(0.18 \%)$. Finally, recoveries of added drug and degradation products were calculated.

\section{Linearity}

Linearity test solutions for the drug were prepared from a stock solution at eleven concentration levels starting from 5 to 100 $\mu \mathrm{g} / \mathrm{mL}$. The standard curve was prepared considering peak area versus concentration data by least-squares linear regression analysis. Linearity test solutions for the degradation products were prepared by diluting stock solution to the required concentrations. The solutions were prepared at eleven concentration levels from LOQ to $200 \%$ of the specification level. The calibration curves were drawn by plotting the peak areas of degradation products against the corresponding concentrations. The slope and Yintercept of the calibration curve were calculated.

\section{Robustness}

To determine robustness, experimental conditions were purposely altered and the resolution of the degradation products and analyte was evaluated. The flow rate was changed by 0.2 units, $\mathrm{pH}$ of buffer from 5.1 to 5.5 and the column temperature was studied at $20^{\circ} \mathrm{C}$ and $30^{\circ} \mathrm{C}$ instead of $25^{\circ} \mathrm{C}$. In all the above conditions, the components of the mobile phase were held constant.

\section{Solution stability and mobile phase stability}

The solution and mobile phase stability of leflunomide and its degradation products were carried out by a leaving spiked sample solution in a tightly capped volumetric flask at room temperature for $48 \mathrm{~h}$. The content of leflunomide and degradation products were determined at $12 \mathrm{~h}$ intervals. The $\%$ RSD for the assay of leflunomide and its degradation products were calculated.

\section{RESULT AND DISCUSSION}

\section{Optimization of chromatographic conditions}

The main difficulty of the chromatographic method was to get the separation of degradation product-1from the leflunomide peak. Attempts were made by using different C18 and C8 stationary phases. Effects of $\mathrm{pH}(2-4)$ and ionic strength (10-20 $\mathrm{mM}$ ) were investigated using phosphate and acetate buffers. It was found that the retention time of leflunomide did not significantly alter at $\mathrm{pH} 2-4$ and ionic strength between $10 \mathrm{mM}$ and $20 \mathrm{mM}$. But the change in the organic composition of mobile phase affects the separation of degradation product-1from leflunomide. So the organic composition of the mobile phase is critical for the separation of degradation product-1from leflunomide. The optimum conditions are given above. In optimized chromatographic conditions leflunomide, degradation product1 and 2 were well separated with resolution greater than 2, typical retention times were shown in Fig. 4.

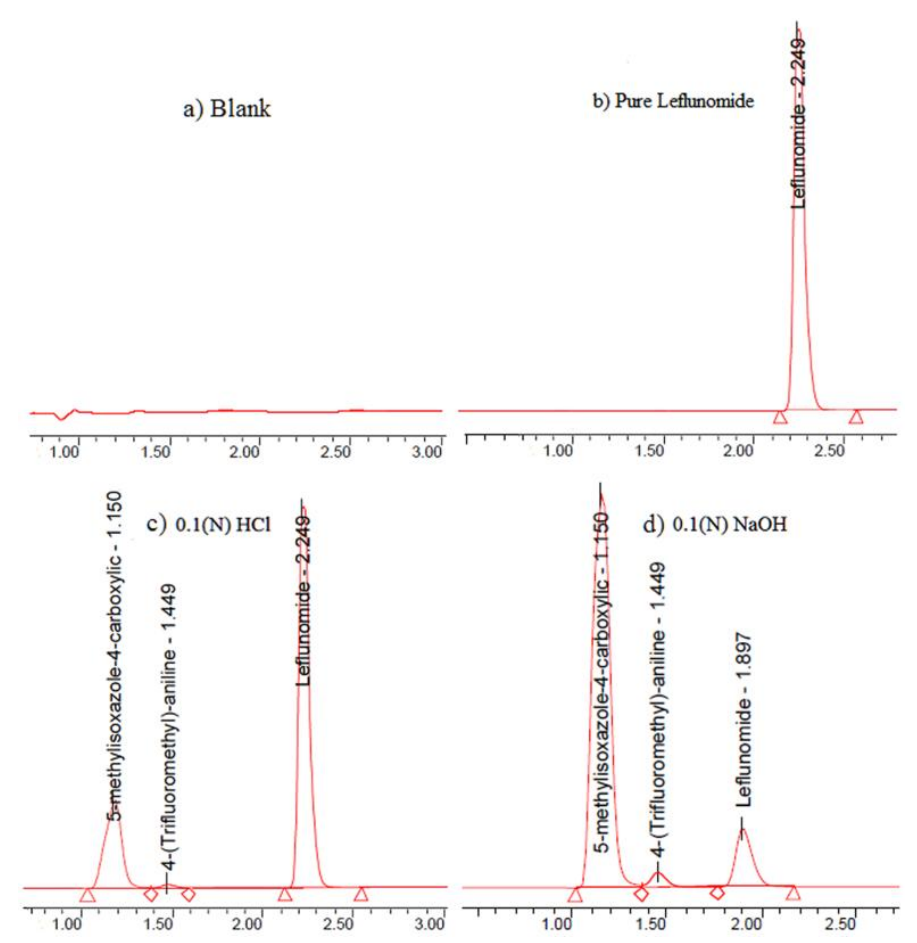




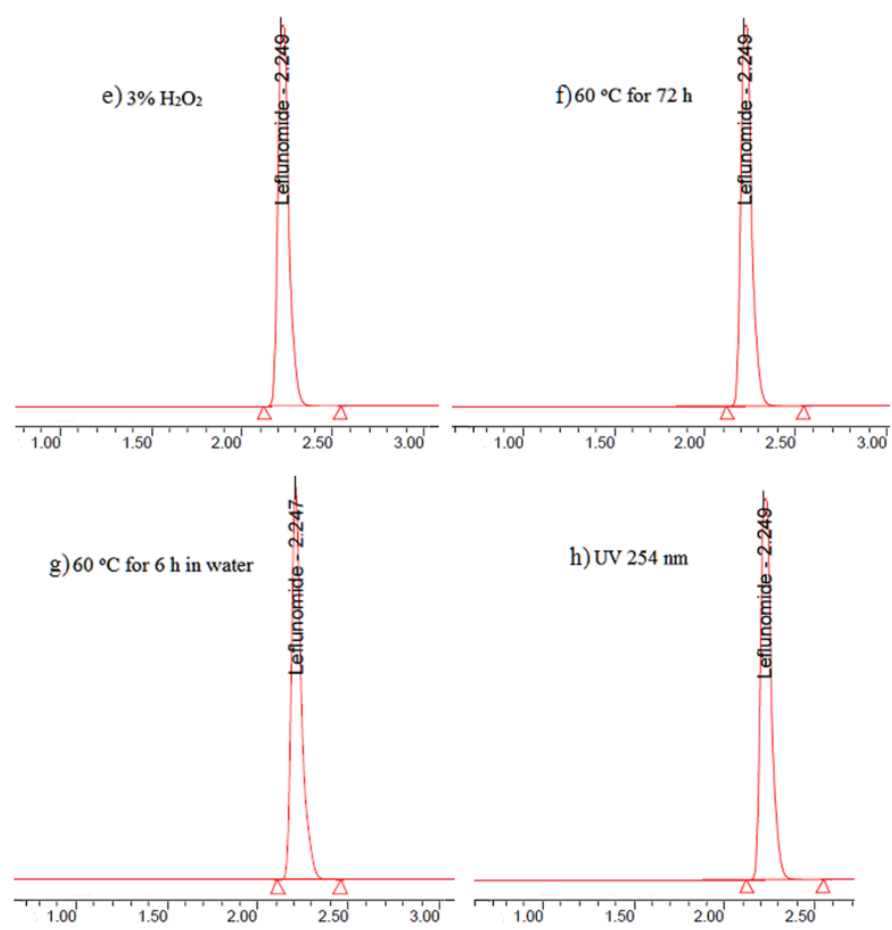

Fig. 4: Representative HPLC chromatograms of lefluriomide pure and stressed samples.

\section{Results of forced degradation studies}

Leflunomide was degraded in acidic and basic media only (Fig. 4). Peak purity test results confirmed that the Leflunomide peak is homogenous and pure in all the analyzed stress samples. The assay of leflunomide is unaffected in the presence of its degradation products, confirms the stability indicating power of the developed analytical method. The summary of forced degradation studies is given in Table 1.

\section{Precision}

The intra and inter assay coefficient of variation for assay of leflunomide during the assay method precision study were within 0.29 and $0.38 \%$, respectively (Table 2).

The intra assay and inter assay coefficient of variation for degradation product-1and 2 in the precision study were within 0.45 and $0.52 \%$, respectively (Table 3 ), confirming good precision of the method.

\section{Limit of Detection and Limit of Quantification}

The limit of detection and limit of quantification of leflunomide was $0.071 \mu \mathrm{g} / \mathrm{mL}$ and $0.243 \mu \mathrm{g} / \mathrm{mL}$ respectively for $20 \mu \mathrm{l}$ injection volume. The coefficient of variation of leflunomide at LOQ concentration was below $2.1 \%$. The limit of detection of degradation product-1 and 2 were 0.042 and $0.036 \mu \mathrm{g} / \mathrm{mL}$ respectively for $20 \mu \mathrm{l}$ injection volume. The limit of quantification of degradation product- 1 and 2 were 0.12 and $0.13 \mu \mathrm{g} / \mathrm{mL}$ respectively for $20 \mu \mathrm{l}$ injection volume. The coefficients of variation at LOQ concentration for degradation product-1and 2 were below $0.6 \%$.

\section{Accuracy}

The percentage recovery of leflunomide in formulation samples ranged from 99.95 to 99.98 . The percentage recovery of degradation product-1and 2 in stress samples ranged from 98.62 to 100 (Table 4).

\section{Linearity}

Linear calibration plots for leflunomide, degradation product- 1 and 2 were obtained by the calibration ranges tested, i.e., $5-100 \mu \mathrm{g} / \mathrm{mL}$ for leflunomide and for degradation products- 1 and 2 from LOQ to $200 \%$ of the specification level. In all the cases, the correlation coefficients obtained were greater than 0.999 .

Table 1: Summary report of forced degradation study.

\begin{tabular}{lcccc}
\multicolumn{1}{c}{ Stress condition } & Time $(\mathbf{h})$ & \% Assay of active substance & \% Assay of degradation products & Mass balance* $(\%)$ \\
\hline Acid Hydrolysis $(0.1 \mathrm{~N} \mathrm{HCl})$ & 4 & 79.89 & 20.09 & 99.98 \\
Basic Hydrolysis $(0.1 \mathrm{~N} \mathrm{NaOH})$ & 4 & 11.73 & 88.26 & 99.99 \\
Oxidation $\left(3 \% \mathrm{H}_{2} \mathrm{O}_{2}\right)$ & 24 & 100.01 & - & 100.01 \\
Dry Heat $\left(60^{\circ} \mathrm{C}\right)$ & 72 & 99.99 & - & 99.99 \\
Wet Heat $\left(60^{\circ} \mathrm{C}\right)$ & 6 & 100 & - & 100 \\
$\mathrm{UV}(254 \mathrm{~nm})$ & 24 & 99.99 & 99.99 & \\
\hline
\end{tabular}

*It is the summation of assay of active substance and degradation products.

Table 2: Intra and Inter assay precision of leflunomide.

\begin{tabular}{|c|c|c|c|c|}
\hline \multirow{2}{*}{$\begin{array}{l}\text { Conc. of leflunomide } \\
(\mu \mathrm{g} / \mathrm{mL})\end{array}$} & \multicolumn{4}{|c|}{ Observed concentration of leflunomide by the proposed method $(\mu \mathrm{g} / \mathrm{mL})$. } \\
\hline & Intra-Day Mean $(n=6)$ & $\% \mathrm{CV}$ & Inter-Day Mean $(n=6)$ & $\% \mathrm{CV}$ \\
\hline 20 & 19.97 & 0.27 & 19.98 & 0.21 \\
\hline 50 & 50.01 & 0.11 & 49.99 & 0.38 \\
\hline 90 & 89.98 & 0.29 & 89.95 & 0.31 \\
\hline
\end{tabular}

$\mathrm{n}=$ Number of determinations.

Table 3: Intra and Inter assay precision of degradation products

\begin{tabular}{|c|c|c|c|c|c|}
\hline Sample & Actual concentration $(\mu \mathrm{g} / \mathrm{mL})$ & Intra-Day Mean $(\mathrm{n}=6)$ & $\% \mathrm{CV}$ & Inter-Day Mean $(\mathrm{n}=6)$ & $\% \mathrm{CV}$ \\
\hline \multirow{3}{*}{$\begin{array}{l}\text { Degradation } \\
\text { product }-1\end{array}$} & 0.06 & 0.061 & 0.19 & 0.062 & 0.16 \\
\hline & 0.12 & 0.121 & 0.23 & 0.122 & 0.18 \\
\hline & 0.18 & 0.179 & 0.11 & 0.181 & 0.17 \\
\hline \multirow{3}{*}{$\begin{array}{c}\text { Degradation } \\
\text { product }-2\end{array}$} & 0.06 & 0.059 & 0.17 & 0.061 & 0.21 \\
\hline & 0.12 & 0.122 & 0.45 & 0.121 & 0.52 \\
\hline & 0.18 & 0.181 & 0.25 & 0.180 & 0.32 \\
\hline
\end{tabular}

$\mathrm{n}=$ Number of determinations. 
Table 4: Recovery result of leflunomide and its degradation products.

\begin{tabular}{|c|c|c|c|c|c|c|c|}
\hline \multirow{4}{*}{$\begin{array}{l}\text { Pure drug } \\
\text { added }(\mu \mathrm{g})\end{array}$} & \multicolumn{2}{|c|}{ Recovery from tablet formulation } & $\begin{array}{c}\text { Degradation } \\
\text { products (dp) }\end{array}$ & $\begin{array}{c}\text { Amount spiked } \\
(\mu \mathrm{g} / \mathrm{mL})\end{array}$ & $\begin{array}{c}\text { Amount recovered } \\
(\mu \mathrm{g} / \mathrm{mL})\end{array}$ & $\begin{array}{c}\text { Mean recovery* } \\
(\%)(n=6)\end{array}$ & $\begin{array}{l}\text { CV } \\
(\%)\end{array}$ \\
\hline & \multirow{3}{*}{$\begin{array}{l}\text { Mean }( \pm \text { SD) } \\
\text { amount }(\mu \mathrm{g}) \\
\text { found* }(n=6)\end{array}$} & \multirow{3}{*}{$\begin{array}{c}\text { Mean }( \pm \mathrm{SD}) \% \\
\text { recovery* } \\
(\mathrm{n}=6)\end{array}$} & \multicolumn{5}{|c|}{ At $40 \%$ level } \\
\hline & & & $\mathrm{dp}-1$ & 0.072 & 0.071 & 98.62 & 0.24 \\
\hline & & & $\mathrm{dp}-2$ & 0.072 & 0.072 & 100.0 & 0.33 \\
\hline \multirow{2}{*}{20} & \multirow{2}{*}{$19.99( \pm .62)$} & \multirow{2}{*}{$99.95( \pm 0.51)$} & & & At $80 \%$ level & & \\
\hline & & & $\mathrm{dp}-1$ & 0.144 & 0.144 & 100.0 & 0.36 \\
\hline \multirow{2}{*}{50} & \multirow{2}{*}{$49.99( \pm 0.87)$} & \multirow{2}{*}{$99.98( \pm 0.72)$} & $\mathrm{dp}-2$ & 0.144 & 0.143 & 99.30 & 0.51 \\
\hline & & & & & At $120 \%$ level & & \\
\hline \multirow{2}{*}{80} & \multirow{2}{*}{$79.98( \pm 0.58)$} & \multirow{2}{*}{$99.97( \pm 0.47)$} & $\mathrm{dp}-1$ & 0.216 & 0.215 & 99.53 & 0.42 \\
\hline & & & $\mathrm{dp}-2$ & 0.216 & 0.215 & 99.53 & 0.43 \\
\hline
\end{tabular}

*Each data represent the average of 6 readings.

\section{Robustness}

In all the deliberately varied chromatographic conditions (flow rate, $\mathrm{pH}$ and column temperature), the resolution between impurities and analyte was found to be more than 2.0.

\section{Solution stability and mobile phase stability}

The \% RSD of the assay of leflunomide during solution stability experiment was within $1.2 \%$. No significant changes were observed in the content of degradation product-1 and 2 during solution stability and mobile phase stability experiments when performed using related substances method. The solution stability and mobile phase stability experiments data confirm that sample solutions and mobile phase used during the assay and related substance determination were stable up to $48 \mathrm{~h}$.

\section{CONCLUSION}

The reverse phase high performance liquid chromatography (HPLC) method developed for quantitative and related substance determination of leflunomide is precise, accurate, rapid and specific. Acidic and basic hydrolysis of leflunomide yielded two degradation products. They were characterized as 5methylisoxazole-4-carboxylic acid and 4-(trifluoromethyl)-aniline. The method was completely validated showing satisfactory data for all the method validation parameters. The developed method can be used for routine analysis and also to check the stability of leflunomide.

\section{ACKNOWLEDGEMENTS}

The authors are grateful to Sun Pharmaceutical Industries Ltd., Sikkim, for providing gift sample of pure leflunomide. Above all, the authors express their gratitude to the authorities of the college of pharmaceutical sciences, Mohuda for providing all the facilities required to accomplish the work.

\section{Financial support and sponsorship: Nil.}

Conflict of Interests: The authors' declare no conflict of interest.

\section{REFERENCES}

Abbas SS, Bebawy LI, Fattah LA. Refaat HH. Spectrophotometric stability-indicating methods for the determination of leflunomide in the presence of its degradates. J AOAC Int, 2006; 89(6):1524-1531.
Fox RI. Renal toxicity associated with disease-modifying antirheumatic drugs used for the treatment of rheumatoid arthritis. J Rheumatol, 1998; 25:53-20.

Kher GJ, Ram VR, Pandya GP, Joshi HS. Development and validation of a stability indicating UPLC assay method for determination of Leflunomide in tablet formulation. Der Chemica Sinica, 2011;2(5):65-74.

Katarzyna RC, Fairbanks LD, Carrey EA, Hawrylowic CM, David FR, Bernhard K, Anne H. Methotrexate inhibits the first committed step of purine biosynthesis in mitogenstimulated human T-lymphocytes: a metabolic basis for efficacy in rheumatoid arthritis. J Biol Chem, 1998; 273:2168221688.

Kher GJ, Ram VR, Dubal KL, Bapodara AH, Joshi HS. Validation of a stability-indicating LC method for assay of leflunomide in tablets and for determination of content uniformity. Int J Chem Tech Res, 2011; 3(2):523-530.

Migita K, Miyashita T, Maeda Y, Nakamura M, Yatsuhashi H, Ishibashi1 HE Guchi K. An active metabolite of leflunomide, A77 1726, inhibits the production of serum an amyloid A protein in human hepatocytes. Rheumatology, 2005; 44: 443-449.

Miron DS, Soldattelli C, Schapoval EES. HPLC with Diode-Array Detection for Determination of Leflunomide in Tablets. Chromatographia, 2006; 63(5-6):283-287

Molinaro M, Carazzone C, Barbano D, Abbiati F, Alessiani M, Regazzi M. Assessment of an LC-MS method for plasma quantification of the new immunosuppressant FK778 through comparison with HPLC-UV. Transplantation Proceedings, 2005; 37(6):2722-2727.

Manna SK, Aggarwal BB. Differential Requirement for $\mathrm{p} 56^{\text {lck }}$ in HIV-tat Versus TNF-Induced Cellular Responses: Effects on NF-kB, Activator Protein-1, c-Jun N- Terminal Kinase, and Apoptosis. J Immunol, 1999; 162:2095-102.

Rao SV, Sunanda KK, Rao NM, Rao AA, Maheswari I, Srinubabu G. Development and validation of LC method for the determination of leflunomide in pharmaceutical formulations using an experimental design. Afr J Pure Appl Chem, 2008; 2(2):10-17.

Shokry DS, Kawy MA,Weshahy SA. Application of spectrophotometric and chromatographic methods for stability indicating determination of leflunomide. J Appl Sci Res, 2012; 8(3):1547-1557.

Vivien C, Bruce GC, Susan ET. Rapid determination of the active leflunomide metabolite A77 1726 in human plasma by high-performance liquid chromatography. J Chromatogr B, 2004; 803(2):331-335.

Yadav B, Nagariya K, Sonaje GR. RP-HPLC stability indicating method development and validation for the estimation of leflunomide and related substance in solid oral formulations. J Global Pharm Tech, 2010; 2(6):40-45.

Yeniceli D, Dogrukol AD, Tuncel M. Determination of leflunomide in tablets by high performance liquid chromatography. J Pharm Biomed Anal, 2006; 40(1):197-201.

\section{How to cite this article:}

Laha TK, Sen S. A Validated Stability Indicating Reversed Phase High Performance Liquid Chromatographic Method of Leflunomide and Characterization of Its Degradation Products through Retro-Synthesis. J App Pharm Sci, 2017; 7 (05): 012-017. 